\title{
SISTEM APLIKASI PEMBAYARAN SISWA MENGGUNAKAN BAHASA PEMROGRAMAN VISUAL BASIC 6.0
}

\author{
Matsna Agustina Rosida, Siti Sufaidah, Tholib Hariono \\ Fakultas Teknologi Informasi Universitas KH.A. Wahab Hasbullah
}

Correspondence Author: masnaagustina@gmail.com

\begin{abstract}
ABSTRAK
Madrasah is an educational institution under the auspices of the Education Department which is moving in the field of school services. Madrasahs that are still manual in handling activities such as recording payment transactions and reporting, manual here in the sense that there is no system that is integrated between parts. Manual record-keeping and reporting are irrelevant or out of date with the fast-paced, precise and accurate progress of the times. Therefore the need for a transition from a manual system to a computerized system. The computerized system to be created should be tailored to the needs of the madrasah. In this research, the writer tries to build madrasah payment system with the database so that it becomes better payment system, effective and efficient and help solve problems faced by the institution in Madrasah Aliyah Negeri Kandangan Office Kediri Regency related to the payment system (like reporting and print receipt). In this case, the database will be used is Access, While the programming using Visual Basic 6.0. In this study discussed the test of the program that has been made. It aims to determine the extent to which the exact execution of programs that have been made and did not rule out knowing weaknesses. So it can be concluded that the program created can run correctly and in accordance with what is expected. Whereas with the construction of this Madrasah Payment Application Sistem, problems in making payment data such as reporting and proof of payment (Receipt) can provide convenience for the officers. Also with database utilization, payment data will be saved automatically.
\end{abstract}

Keywords: Access, Visual Basic 6.0, Student Payout.

\section{INTISARI}

Madrasah adalah sebuah instansi pendidikan di bawah naungan Dinas Pendidikan yang begerak dalam bidang pelayanan sekolah. Madrasah yang selama ini masih manual dalam menangani kegiatan-kegiatan seperti pencatatan transaksi pembayaran dan pembuatan laporan, manual disini dalam artian belum ada sistem yang terintegrasi antar bagian. Pencatatan dan pembuatan laporan secara manual sudah tidak relevan atau sudah tidak sesuai lagi dengan kemajuan zaman yang dituntut serba cepat, tepat dan akurat. Maka dari itu perlunya transisi dari sistem manual ke sistem komputerisasi. Sistem komputerisasi yang akan dibuat harus disesuaikan dengan kebutuhan madrasah. Pada penelitian ini, penulis mencoba untuk membangun sistem pembayaran madrasah dengan database sehingga menjadi sistem pembayaran yang lebih baik, efektif dan efesien serta membantu memecahkan masalah yang dihadapi oleh instansi di kantor Madrasah Aliyah Negeri Kandangan Kabupaten Kediri terkait dengan sistem pembayaran (seperti pembuatan laporan dan cetak kwitansi). Dalam hal ini database yang akan dipakai adalah Access, Sedangkan pemrogramannya memakai Visual Basic 6.0. Pada penelitian ini dibahas mengenai pengujian dari program yang telah dibuat. Hal ini bertujuan untuk mengetahui sejauh mana ketepatan eksekusi program yang telah dibuat serta tidak menutup kemungkinan mengetahui kelemahannya. Sehingga dapat disimpulkan program yang dibuat dapat berjalan secara benar

ISSN Print $\quad$ : 1979-7141 
dan sesuai dengan apa yang diharapkan. Bahwa dengan dibangunnya Sistem Aplikasi Pembayaran Madrasah ini, permasalahan dalam pembuatan data pembayaran seperti pembuatan laporan dan bukti pembayaram (Kwitansi) dapat memberi kemudahan bagi petugas. Juga dengan pemanfaatan database, data-data pembayaran akan tersimpan secara otomatis.

Kata kunci : Access, Visual Basic 6.0, Pembayaran Siswa.

\section{Pendahuluan}

Sistem pembayaran biaya sekolah di Madrasah Aliyah Negeri Kandangan Kediri masih manual. Kwitansi dibuat dengan tulisan tangan sehingga mengakibatkan kwitansi tidak dapat dicetak ulang. Selain membuat kwitansi, karyawan mencatat pembayaran dikomputer, lebih tepatnya di Microsoft Excel. Hal ini membuat karyawan bekerja dua kali. Lembar kerja Microsoft Excel kurang informatif, terlihat rumit karena terdiri dari banyak kolom. Jika terjadi salah ketik dibagian rumus bisa berakibat semua perhitungan menjadi salah. Madrasah Aliyah Negeri Kandangan Kediri menetapkan biaya sekolah yang berbedabeda di setiap tahun angkatan. Perbedaan biaya sekolah tersebut membuat petugas sering lupa jumlah biaya yang seharusnya dibayar oleh siswa atau wali murid.

Madrasah Aliyah Negeri Kandagan Kediri membutuhkan sistem pembayaran madrasah yang terkomputerisasi untuk mengatasi masalah-masalah diatas. Sistem informasi akan mengurangi terjadinya kesalahan, meringankan pekerjaan dan memberikan informasi yang akurat. Sistem pembayaran biaya sekolah akan mendukung kelancaran administrasi dan pengambilan keputusan di Madrasah Aliyah Negeri (MAN) Kandagan Kediri.

\section{Metodologi}

\subsection{Alat dan Bahan}

Bahan penelitian yang digunakan dalam proses penelitian ini berasal melalui wawancara karyawan bagian administrasi di Madrasah Aliyah Negeri (MAN) Kandangan Kediri, studi pustaka, jurnal, artikel dan buku pendukung.

Dalam melakukan penelitian ini, alat yang digunakan untuk keberhasilan penelitian adalah sebagai berikut :

a. Perangkat Keras (Hardware)

1 Unit CPU minimal Pentium 4, RAM minimal 512 MB, Hardisk minimal 20 G, LCD 14 inc, Keyboard, Mouse, Printer IP 2700.

b. Perangkat Lunak (Software)

Windows7, Visual Basic 6.0, Microsoft Acces 2007, Component One.

\subsection{Analisis Sistem}

Dalam penelitian ini dapat disimpulkan kekurangan pada sistem tersebut :

1. Karyawan melakukan kerja 3 kali setiap terjadi pembayaran, yang pertama karyawan membuatkan kwitansi, yang kedua kwitansi tersebut harus dicatat di buku keuangan dan yang ketiga memasukkan di lembar kerja Microsoft Excel.

2. Sulit mencari data-data yang dibutuhkan karena banyaknya berkas pembayaran.

3. Lambatnya dalam melakukan transaksi pembayaran dan dalam pembuatan laporan keuangan.

4. Kwitansi bisa hilang atau rusak sebelum dicatat.

Dari data kelemahan dalam sistem tersebut, maka perlu dibutuhkan sebuah sistem baru untuk menjawab kelemahan - kelemahan dalam sistem lama tersebut. Dibutuhkan sebuah sistem yang terintegrasi antara bagian / unit satu dengan yang lainnya. Untuk lebih jelasnya, akan dijelaskan kebutuhan sistem dalam menyelesaikan masalah atau kelemahan sistem yang lama,yaitu :

1. Untuk menangani masalah mulai dari pencatatan data, pencarian data, pembuatan laporan, pembayaran administrasi dan biaya serta untuk memperoleh informasi yang 
cepat akurat baik informasi keuangan ataupun lainnya maka dibuatkan Sistem Aplikasi Pembayaran Madrasah. Sistem ini akan menyelesaikan masalah atau kelemahan dalam sistem yang lama, misalnya :

2. Pencatatan data yang sangat benyak akan tersimpan semua dalam database. Yang database tersebut tentu saja akan tersimpan dalam hardisk komputer sehingga Pencarian data yang cepat dan akurat, karena data yang tersimpan dalam database tadi diolah menjadi sebuah informasi yang diperintah oleh bahasa pemograman Visual Basic 6.0.

3. Pembuatan laporan yang mudah dan cepat karena data - data yang tersimpan dalam database akan diolah sedemikian rupa oleh perintah Bahasa Pemograman Visual Basic 6.0 yang akan menjadi informasi yang dibutuhkan dalam bentuk laporan yang ditampilkan dalam software Component One yang sudah terkoneksi dengan Database Microsoft Acces dan Bahasa Pemograman Visual Basic 6.0

4. Kwitansi dibuat secara otomatis oleh komputer saat siswa/walimurid membayar adminstrasi atau biaya, sehingga tidak bisa terjadi kecurangan yang dilakukas petugas kasir

5. Sistem akan dibuat terintegrasi antar bagian / unit sehingga informasi yang diperoleh antar bagian adalah sama

6. Pimpinan akan cepat mengambil sebuah keputusan karena mudah mencari informasi informasi yang dibutuhkan

\subsection{Perancangan Interface Program Pembayaran}

Perancangan interface Program Pembayaran ini dibangun dengan bahasa pemprograman Visual basic 6.0 dengan Microsoft Acces sebagai databasenya. Adapun sebagian bentuk perancangan form yang dibutuhkan adalah sebagai berikut :

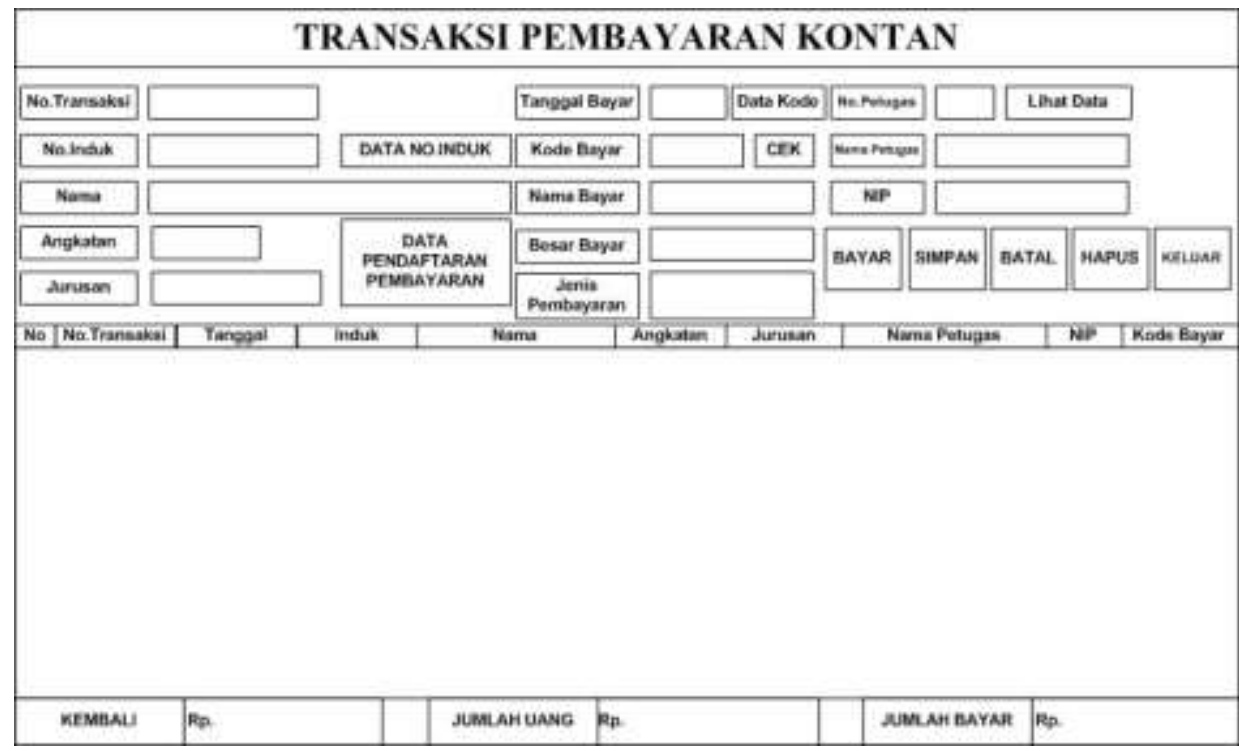

Gambar 1 : Perancangan Form Transaksi Pembayaran Kontan

Perancangan form pembayaran kontan ini digunakan untuk pembayaran-pembayaran kontan yang tidak untuk di angsur pembayarannya.

Misalnya pembayaran daftar ulang siswa, dan lain-lain. 


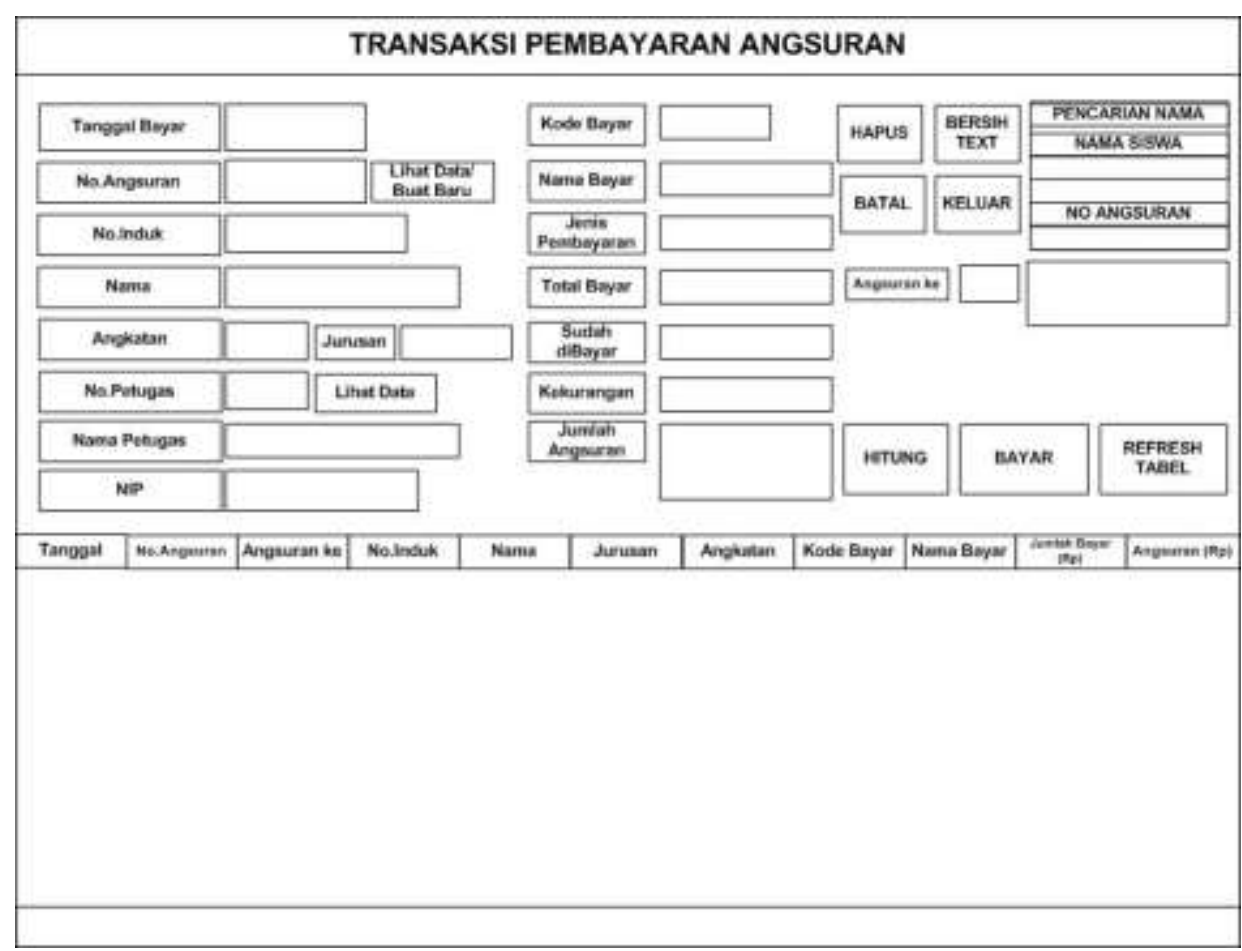

Gambar 2 : Perancangan Form Transaksi Pembayaran Angsuran

Perancangan form pembayaran angsuran ini digunakan untuk pembayaran-pembayaran angsuran yang dapat di angsur jenis pembayarannya.

Misalnya pembayaran infaq, pembayaran buku, pembayaran sekolah dan lain-lain.

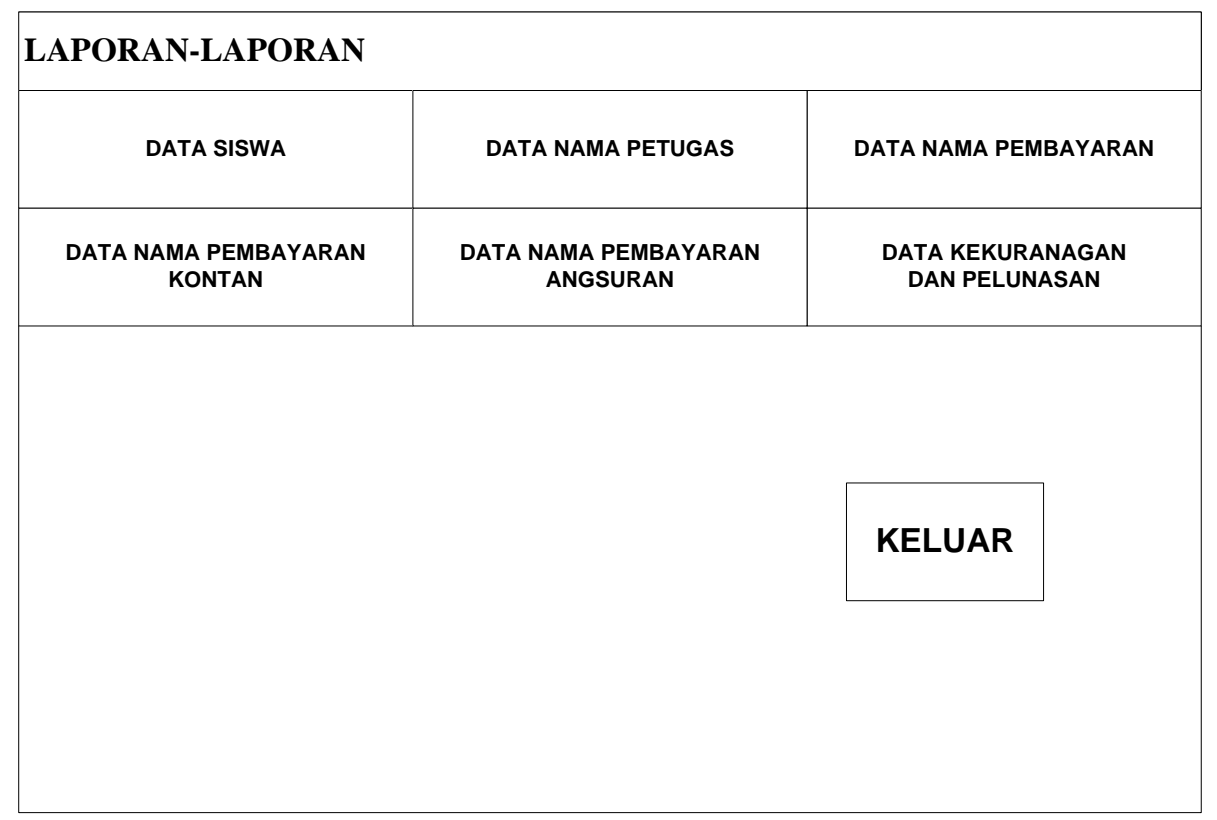

Gambar.3 : Perancangan Form Laporan

Desain halaman laporan digunakan untuk mengetahui laporan data-data, baik laporan data siswa, data petugas, data nama pembayaran, data pembayaran kontan, data nama pembayaran angsuran dan data kekurangan dan pelunasan pembayaran siswa. 


\section{Hasil dan Pembahasan}

\subsection{Hasil Interface Aplikasi}

Setelah dilakukan perancangan interface, dilakukan pengujian untuk melihat apakah hasil perancangan dapat berjalan sesuai harapan. Adapun sebagian hasil yang didapatkan adalah sebagai berikut :

1. Halaman Transaksi Pembayaran Kontan dan Pembayaran Angsuran

Halaman form transaksi pembayaran kontan dan pembayaran angsuran digunakan untuk input data transaksi pembayaran kontan dan pembayaran angsuran siswa.

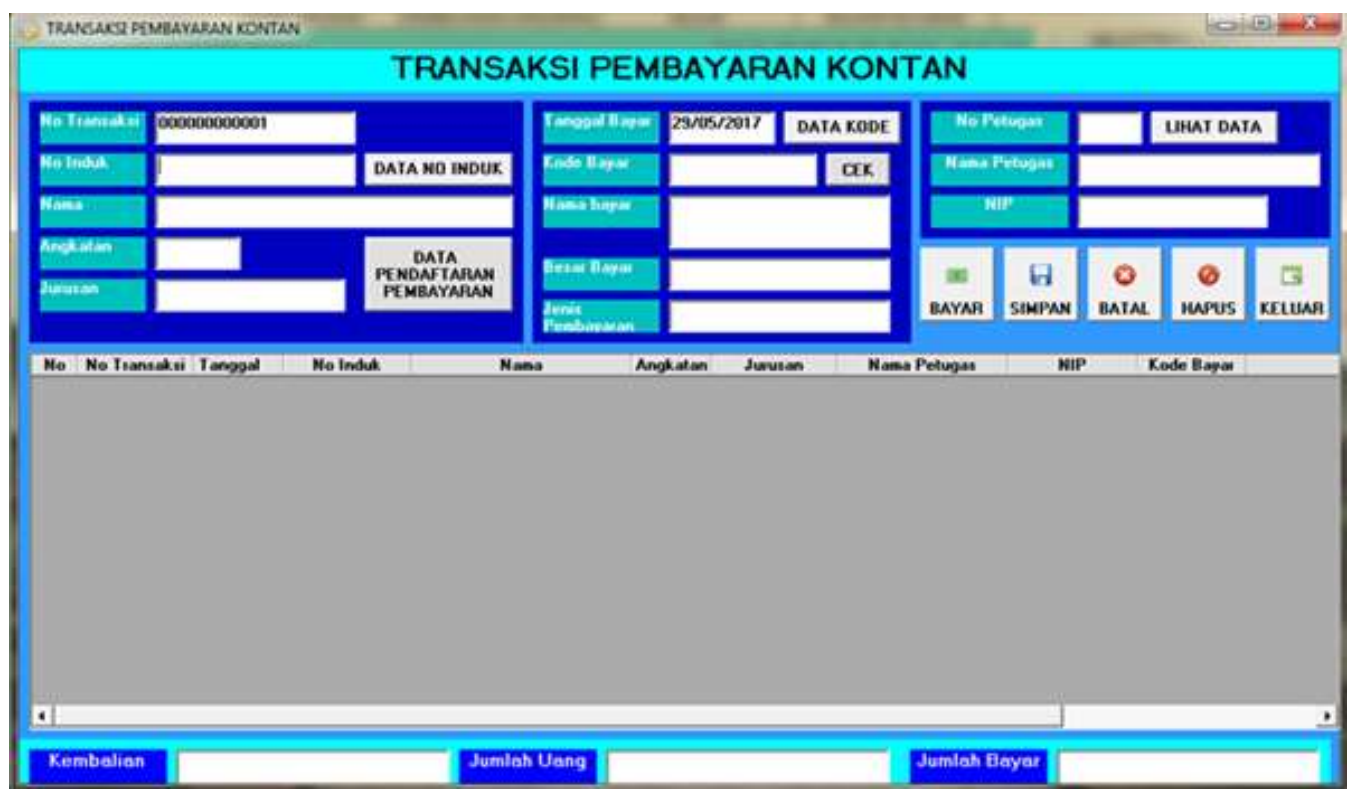

Gambar 4 : Halaman Transaksi Pembayaran Kontan

Pada form transaksi pembayaran kontan ini, digunakan untuk menginputkan siswa yang melakukan transaksi pembayaran kontan.

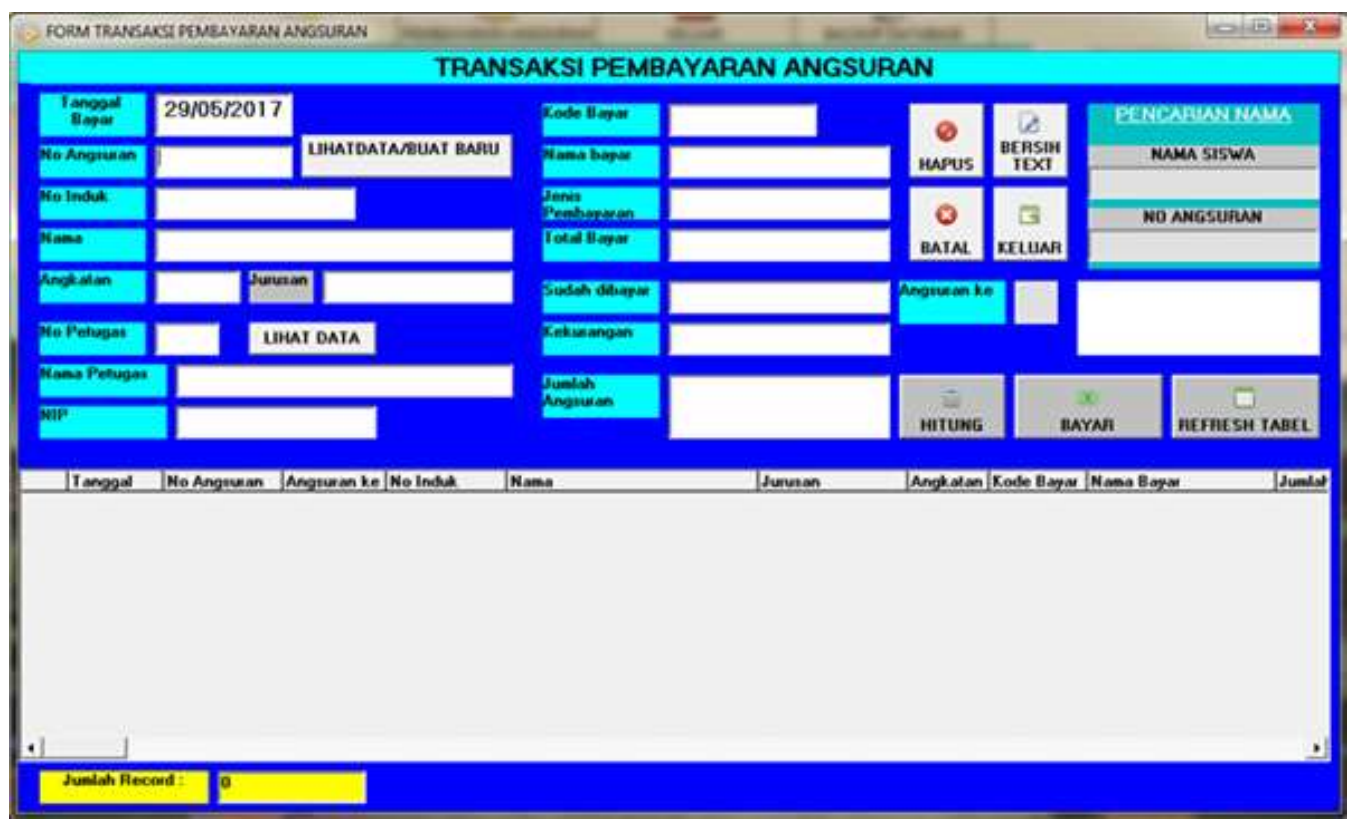

Gambar 5 : Halaman Transaksi Pembayaran Angsuran 
Pada form transaksi pembayaran Angsuran ini, digunakan untuk menginputkan siswa yang melakukan transaksi pembayaran Angsuran.

2. Halaman Laporan-Laporan

Halaman laporan-laporan digunakan untuk mengetahui laporan-laporan data.

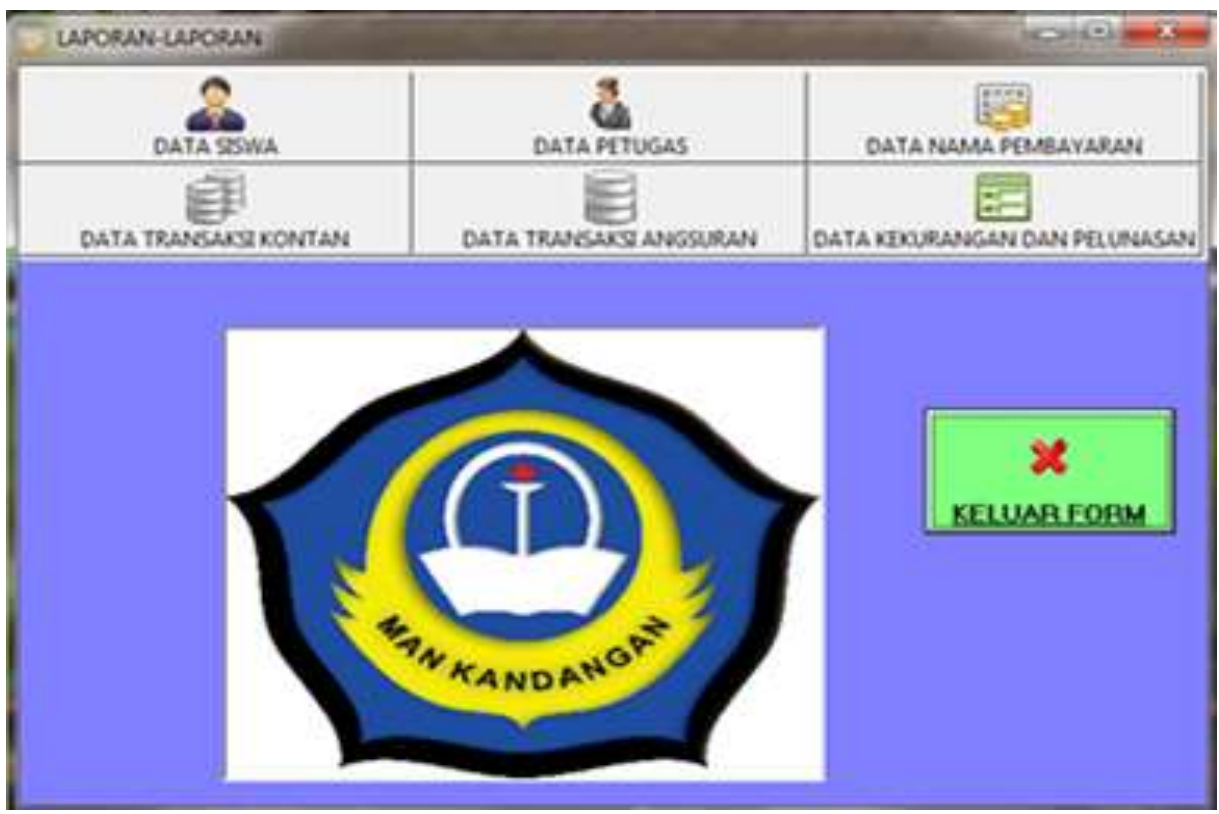

Gambar 6 : Halaman Laporan-Laporan

Pada form laporan ini, digunakan untuk mengetahui laporan-laporan data. Seperti, data siswa, data petugas, data nama pembayaran, data transaksi pembayaran kontan, data transaksi pembayaran angsuran, dan data kekurangan dan pelunasan pembayaran siswa.

\section{Uji Coba Program}

Uji coba program Sistem Pembayaran Siswa dilakukan dengan menggunakan metode Black Box Testing. Metode Black Box Testing merupakan pengujian program yang mengutamakan pengujian terhadap kebutuhan fungsi dari suatu program. Tujuan dari metode Black Box Testing ini adalah untuk menemukan kesalahan fungsi pada program

Tabel 1: Pengujian Black box Pada Menu Login Admin.

\begin{tabular}{|c|c|c|c|c|}
\hline $\begin{array}{l}\text { Sekenario } \\
\text { Pengujian }\end{array}$ & Test Case & $\begin{array}{l}\text { Hasil Yang } \\
\text { diharapkan }\end{array}$ & Hasil Pengujian & Kesimpulan \\
\hline $\begin{array}{l}\text { Mengisi } \\
\text { Username } \\
\text { dan } \\
\text { Password } \\
\text { dengan } \\
\text { benar, Klik } \\
\text { Login }\end{array}$ & & $\begin{array}{l}\text { Sistem } \\
\text { menerima } \\
\text { login dan } \\
\text { masuk ke } \\
\text { home Admin }\end{array}$ & hending & Valid \\
\hline
\end{tabular}


Lanjutan Tabel 1: Pengujian Black box Pada Menu Login Admin.

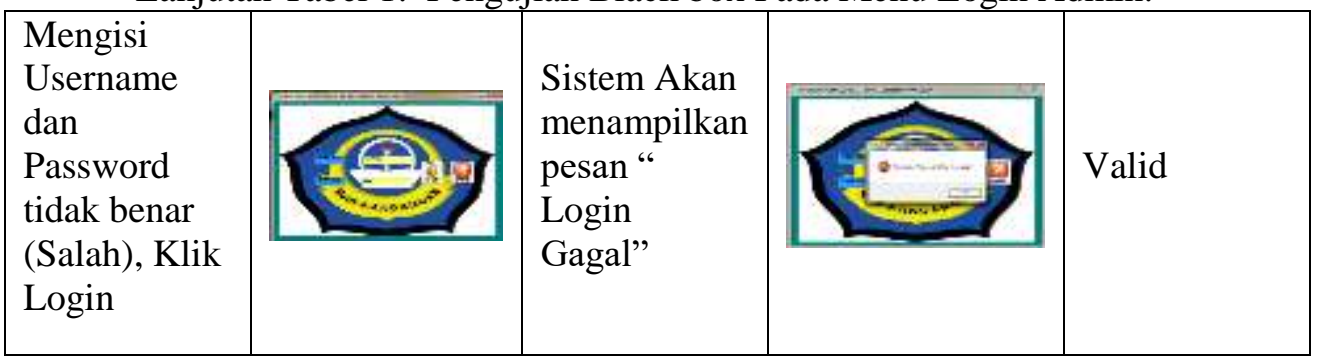

Tabel 2: Pengujian Black box Pada Menu Bayar.

\begin{tabular}{|c|c|c|c|c|}
\hline $\begin{array}{l}\text { Sekenario } \\
\text { Pengujian }\end{array}$ & Test Case & $\begin{array}{l}\text { Hasil Yang } \\
\text { diharapkan }\end{array}$ & Hasil Pengujian & Kesimpulan \\
\hline $\begin{array}{l}\text { Mengisi } \\
\text { NIM dan } \\
\text { Jumlah } \\
\text { Bayar } \\
\text { dengan } \\
\text { benar, Klik } \\
\text { Simpan }\end{array}$ & 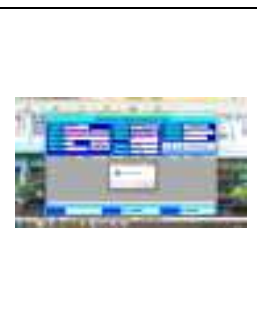 & $\begin{array}{l}\text { Sistem } \\
\text { menampilkan } \\
\text { data } \\
\text { pembayaran }\end{array}$ & 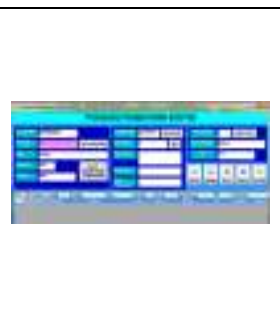 & Valid \\
\hline $\begin{array}{l}\text { Tidak } \\
\text { mengisi NIM } \\
\text { maupun } \\
\text { Jumlah } \\
\text { Bayar, Klik } \\
\text { Simpan }\end{array}$ & 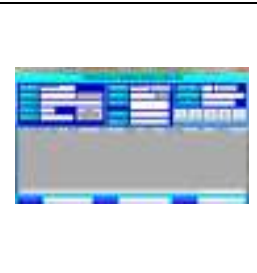 & $\begin{array}{l}\text { Sistem Akan } \\
\text { menampilkan } \\
\text { pesan " } \\
\text { Bahwa data } \\
\text { belum diisi" }\end{array}$ & 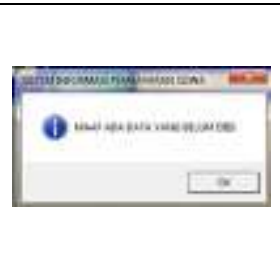 & Valid \\
\hline
\end{tabular}

Tabel 3: Pengujian Black box Pada Cetak Kwitansi.

\begin{tabular}{|l|l|l|l|l|}
\hline $\begin{array}{l}\text { Sekenario } \\
\text { Pengujian }\end{array}$ & Test Case & $\begin{array}{l}\text { Hasil Yang } \\
\text { diharapkan }\end{array}$ & Hasil Pengujian & Kesimpulan \\
\hline $\begin{array}{l}\text { Klik Cetak } \\
\text { Laporan } \\
\text { pembayaran } \\
\text { pelunasan, isi } \\
\text { data siswa } \\
\text { pada form } \\
\text { pembayaran }\end{array}$ & & $\begin{array}{l}\text { Sistem } \\
\text { menampilkan }\end{array}$ & $\begin{array}{l}\text { Kwitansi } \\
\text { Pembayaran }\end{array}$ & \\
\hline
\end{tabular}

\section{Kesimpulan}

Dari pembahasan yang telah diuraikan tersebut maka penulis dapat menyimpulkan bahwa dengan dibangunnya Sistem Aplikasi Pembayaran Madrasah ini diharapkan permasalahan dalam pembuatan data pembayaran seperti pembuatan laporan dan bukti pembayaram (Kwitansi) dapat memberi kemudahan bagi petugas. Juga dengan pemanfaatan database, data-data pembayaran akan tersimpan secara otomatis. 


\section{DAFTAR PUSTAKA}

Al-Bahra Bin Ladjamudin. 2005. Analisis dan Desain Sistem Informasi. Yogyakarta : Graha Ilmu.

Fathansyah. 2002. Basis Data. Informatika. Bandung.

Fowler, Martin. 2005. UML Distilled Edisi 3, Yogyakarta: Andi.

Jogiyanto H.M, 1999, Analisis dan Disain Sistem Informasi, Andi, Yogyakarta.

Jogiyanto Hartono, 2004, Analisis dan Desain, Yogyakarta:Andi Offset.

Kamus Besar Bahasa Indonesia. (1998). Jakarta : Pustaka Amani

Kusrini, 2007. Konsep dan Aplikasi Sistem Pendukung Keputusan. Penerbit: Yogyakarta.

Kusrini. 2007. Konsep dan Aplikasi Sistem Pendukung Keputusan. Yogyakarta : Penerbit Andi

McLeod, R. \& Schell, G.P. (2007). Management Information Sistem, edisi ke-10. Pearson Prentice Hall, New Jersey.

Suhata. 2005. VB Sebagai Pusat Kendali Peralatan Elektronik. Jakarta: PT.Elex Media Computindo. 